\title{
Európai stratégiai autonómia - A közös védelem alapjai és korlátjai
}

\begin{abstract}
Az Európában és szomszédságában az elmúlt évtizedben kialakult válságok nyomán szükségszerüvé vált annak megvitatása, hogy a kontinens államai hogyan képesek növelni biztonságukat, és akár az Amerikai Egyesült Államok nélkül, önállóan (is) cselekedni. A tanulmány központi kérdése, hogy létre lehet-e hozni európai stratégiai autonómiát, amelyben a kritikus pont közép- és hosszú távon egyaránt az együttmüködési hajlandóság. A lehetőségek feltérképezése érdekében, először a közös stratégiai kultúra elemeit, majd az európai államok együttmüködési hajlandóságát, végül a stratégiai autonómia kialakitásához füződő nemzeti álláspontok hasonlóságait és különbözőségeit vizsgálom primer kutatási eredmények másodelemzésével és szintetizálásával. A vizsgálat arra mutat rá, hogy az európai államokat továbbra is stratégiai diszharmónia jellemzi, az együttmüködési kultúra tekintetében az államok közti preferenciák nagymértékben területalapúak, a stratégiai autonómia esetében pedig jelenleg az önálló cselekvési képesség értelmezésében és ambíciószintjében is jelentősek az eltérések.
\end{abstract}

Kulcsszavak: Európa, Európai Unió, stratégiai autonómia, védelempolitika, Németország, NATO, PESCO

\section{Szabolcs Laura: European Strategic Autonomy - The Foundations and Limits of Cooperation}

As a consequence of the crises that had emerged in Europe and its neighbourhood in the past decade, starting the discussion on the possibilities of increasing the security of the continent's states and their ability to act independently - even without the United States - became necessary. The central question of this study is whether it would be possible to create European strategic autonomy, in which the critical element is the willingness to cooperate in the mid- to long-term. To map up possibilities, first the elements of strategic culture, then the willingness of European states to cooperate is examined, and finally the similarities and differences of national positions regarding the creation of strategic autonomy are evaluated based on a secondary analysis and synthesis of primary research results. The analysis points out that European states are still characterised by strategic disharmony, while the preferences of states regarding their willingness to cooperate are significantly territorial. Also, currently there are significant differences in the interpretation of strategic autonomy and their level of ambition thereof.

Keywords: Europe, European Union, strategic autonomy, defence policy, Germany, NATO, PESCO

Szabolcs Laura, a Nemzeti Közszolgálati Egyetem, Nemzetközi Biztonság- és Védelempolitika szak MSc hallgatója, e-mail: szabolcsvlaura@gmail.com 


\section{Bevezetés}

Európában és annak szomszédságában az utóbbi években több válság - a 2008-as grúzorosz háború, az Arab Tavasz (2010), a 2014 óta tartó ukrán válság, a migrációs és menekültválság (2015), a Brexit (2016-) vagy éppen Donald Trump elnöksége (2017-) - is hozzájárult ahhoz, hogy szükségszerüvé vált annak megvitatása, hogy Európa hogyan képes növelni a biztonságát, és akár az Amerikai Egyesült Államok (Egyesült Államok) nélkül, önállóan (is) cselekedni. A vitával összefüggésben ki kell emelnünk a „stratégiai kultúra”, az „együttmüködési kultúra és formációk” és a „stratégiai autonómia” fogalmát, amelyeknek definiálása szükséges a téma mélyebb megértéséhez és egyben tanulmányom három alapvető pillérét is képezik.

A stratégiai kultúra fogalmát Jack Snyder a következőképpen határozta meg: „eszmények, feltételezett érzelmi válaszok és rögzült szokások (viselkedésminták) összessége", ${ }^{2}$ amely a biztonság- és védelempolitika területén formálja az adott közösség érdekeit és cselekvéseit. ${ }^{3}$ Ebben az esetben a nemzeti sajátosságok befolyása a meghatározó, de nem elhanyagolható a nemzetközi normák hatása sem. ${ }^{4} \mathrm{~A}$ közös stratégiai kultúra kialakítását politikai (hasonló fenyegetettségpercepció), katonai (közös döntéshozatal, műveleti tervezés, közös képességek, haderőelemek) és gazdasági (közös finanszírozási mechanizmus) szempontok egyaránt meghatározzák. A nemzeti stratégiai kultúrák vizsgálatát ezért három tanulmány, illetve tanulmánykötet ${ }^{5}$ módszertani megközelítése nyomán az aktuális stratégiai dokumentumok elemzésével végzem el.

A Biehl - Griegerich - Jonas kötet négy dimenziót értékel: a külpolitikai orientációt, a nemzetközi ambíciószintet, a katonai erő használatához füződő viszonyt és a belső döntéshozatalt, ${ }^{6}$ amelyekhez kifejtő kérdéseket is meghatároz. Ezek közül az első háromra térek ki, az utolsót nem vizsgálom belpolitikai jellege miatt. Az ECFR-elemzés nem ismerteti részletes módszertanát, viszont kategóriákba rendszerezi az országokat biztonsági és védelmi stratégiai dokumentumaik alapján: stratégák, globalisták, lokalisták, kimaradók és sodródók. Mivel a besorolás 2013-as, kutatásomban áttekintem az azóta elfogadott stratégiai dokumentumokat (jelen esetben beleértve a nemzeti Fehér Könyveket, védelmi és biztonsági stratégiákat, haderőfejlesztési programokat), egyúttal a másik két elemzésben meghatározott szempontrendszerrel is frissítve, pontosítva az ECFR rendszerezését.

A közös stratégiai kultúra kialakításában szerepet játszik az együttműködési kultúra, amely szintén eltérhet a tagállamoknál. Ennek az aspektusnak a vizsgálatához az ECFR 2018-as EU Coalition Explorer címü kiadványát használom fel, amelyhez a kutatók online kérdőív segítségével végeztek közvélemény-kutatást olyan európai döntésformálók, politikai szakértők körében, akik nemzeti kormányokban, politikai pályán, a kutatói szfé-

\footnotetext{
Szegő László: A stratégiai kultúráról. [online], Hadtudomány, 23. (2013), 1. 45-54. 46. [2019. 07. 15. ].

Heiko Biehl - Bastian Giegerich - Alexandra Jonas (eds.): Strategic Cultures in Europe - Security and Defence Policies Across the Continent. Potsdam, Springer VS, 2013. 12.

4 Neil Winn: Beyond Strategic Culture? Grand Strategy, the European Union and Security Cooperation. [online], Leeds, POLIS, 2015. 5. Forrás: aei.pitt.edu [2019. 11. 02.]

5 Biehl-Giegerich-Jonas (eds.) (2013) i. m.; Olivier De France - Nick Witney: Europe's Strategic Cacophony. [online], ECFR, 2013. [2019. 07. 10.].; Csiki Tamás: Az új Nemzeti Katonai Stratégia a nemzetközi tapasztalatok tükrében. [online], Nemzet és Biztonság - Biztonságpolitikai Szemle, 7. (2014), 2. 45-61. [2019. 07. 10.].

6 Biehl-Giegerich-Jonas (eds.) (2013) i. m. 13.
} 
rában, illetve oktatási intézményekben vagy a médiában dolgoznak. A kutatás kiterjedt a preferenciákra, prioritásokra, potenciális együttmüködési lehetőségekre az Európai Unió (EU, Unió) tagállamai között. A közös védelmi struktúra kialakításában négyféleképpen csoportosította a kooperációs preferenciákat: uniós keretek között minden tagállam részvételével, külön szerződéses alapon - „védelmi Schengen” -, ad hoc koalíciókban, illetve elkülönítette a kizárólag nemzeti védelmi törekvéseket. Tanulmányom második pilléreként e véleményfelmérés adatait vetem össze, keresve egy lehetséges koalíciós formát a védelmi integráció mélyítésére.

A 2016-os EU Globális Stratégia is használta a „stratégiai autonómia” kifejezést, amelynek három fajtájáról ejt szót: döntéshozatali, információs és cselekvési autonómia - ez alapján az uniós tagállamoknak különbözik az elképzelése arról, hogyan is lehetne megvalósítani a közös stratégiai autonómiát. Többek között Franciaország számára ez a „szabad döntési és cselekvési képességet [jelenti] egy független világban”, tehát saját nemzeti stratégiai autonómiája kiterjesztését, más országoknál - mint például Svédország, Hollandia vagy Lengyelország - egyfajta „vitatott célként” jelenik meg, és inkább a más szereplőktől való függetlenségre helyezik a hangsúlyt. ${ }^{7}$ Dolgozatom harmadik részét ehhez kapcsolódva az ECFR ugyancsak újító kutatásának ${ }^{8}$ adataira alapozom, amelyben az ECFR nemzeti kutatói döntéshozókkal, elemzőkkel készített interjúkat, politikai dokumentumokat, tudományos elemzéseket, médiaanalízist és véleménykutatásokat vetettek össze.

Tanulmányom központi kérdése, hogy létre lehet-e hozni közép- vagy hosszú távon az európai stratégiai autonómiát. Ehhez kapcsolódó hipotézisem, hogy bár a közös stratégiai kultúra kialakításának néhány kritériuma már formálódik (hasonló fenyegetettségpercepció nagyobb országcsoportok között, közös finanszírozási mechanizmus), a kritikus pont közép- és hosszú távon egyaránt az együttmüködési hajlandóság. A kérdés vizsgálata azért is fontos, mert napjaink európai politikájában a témának gyakorlati relevanciája is van a nemzeti döntéshozóknál.

\section{Tagállami stratégiai kultúrák}

Az említett de France - Witney elemzés és Biehl - Giegerich - Jonas tanulmánya által meghatározott szempontok szerint tekintettem át a 28 EU-tagállam (jelenleg a Brexittel nem számolva) 2013 óta kiadott stratégiai-védelmi dokumentumait, felhasználva Csiki Tamás cikkében feltüntetett elemzési kérdéseket is. Mindezek alapján besoroltam az országokat a „nagy stratéga - stratéga - globalista - lokalista - kimaradó - sodródó” kategóriákba. Elemzésemben stratégának számít az az állam, amely széles körben áttekinti az aktuális geostratégiai trendeket, átfogóan azonosít fenyegetéseket, kockázatokat és lehetőségeket. A külső és belső fenyegetések közti határ elmosódik. Emellett meghatároz magas szintü konkrét célokat, részcélokat és müveleti ajánlásokat, amelyekhez széles spektrumú eszközrendszert is azonosít, és a megvalósítását közösen képzeli el valamely nemzetközi szervezet, többnemzeti megállapodás keretében. A globalista országok stratégiai perspektívája széles,

Ez jól látszik ebben a tanulmányban: Ulrike Franke -Tara Varma: Independence play: Europe’s pursuit of strategic autonomy. [online], ECFR, 2018. [2019. 07. 10.].

8 Uo. 
viszont az eszközrendszer és a végrehajtás hiányos. A lokalisták nemzetközi kitekintésének súlypontja a közvetlen földrajzi környezetre fókuszál, kisebb keretek között, ellenben részletes stratégiai célokkal számolnak - ehhez relatíve kevés eszköz társul. A kimaradóknál - semlegességük vagy stratégiai helyzetük miatt - kis hangsúlyt kapnak a védelmi dokumentumok, illetve a céljaik megvalósítását többnyire nemzeti szinten tervezik. A sodródók laza stratégiai irányelveket fogalmaztak meg, vagy idejétmúlt dokumentumokkal rendelkeznek. ${ }^{9}$

$\mathrm{Az}$ országok védelmi kiadványaiban nem feltétlenül jelenik meg minden szempont, szinte az összes tagállam más-más módon határozza meg stratégiai kultúráját, így a fentebb említett szempontokat csak irányelveknek tekinthetjük az elemzéshez. Az 1. ábrán a de France - Witney elemzés eredményeit frissítve láthatjuk a stratégiai látásmód és a védelmi dokumentumok aktualitása szerint a tagállamok besorolását.

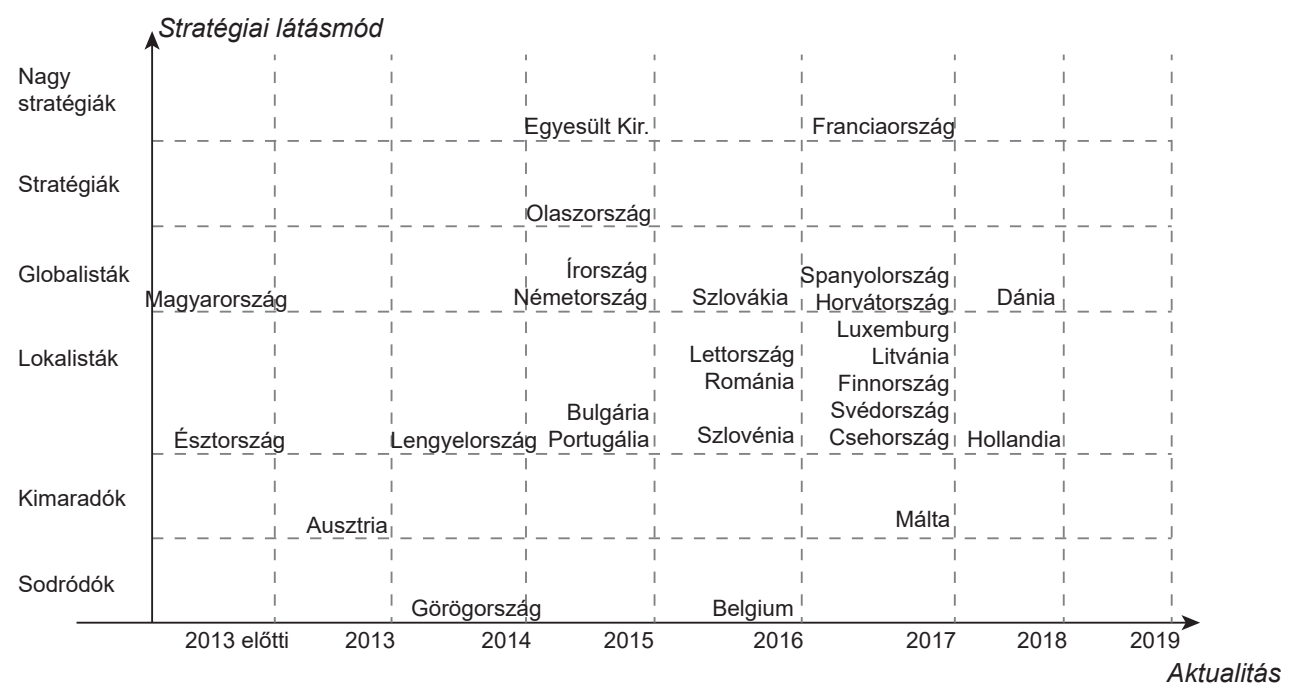

1. ábra: Az EU-28-ak nemzeti stratégiai kultúrájának komparatív jellemzése

Forrás: a szerző szerkesztése de France - Witney (2013) i. m. aktualizált eredményei alapján

\section{Nagy stratégák}

A nagy stratégákhoz az Egyesült Királyságot és Franciaországot soroltam. Az Egyesült Királyság rendelkezik egy 2015-ös Nemzeti Biztonsági Stratégia és Stratégiai Védelmi és Biztonsági Felülvizsgálattal, ennek végrehajtását elősegítő Nemzeti Biztonsági Képességfelülvizsgálattal. ${ }^{10}$ Globális kitekintéssel és átfogó biztonságértelmezéssel rendelkezik, emellett ambíciószintjét haderőnemenként fejti ki. A NATO, a Brit Nemzetközösség

De France - Witney (2013) i. m.

10 A dokumentumok címének fordítása szabadfordítás, lábjegyzetben jelzem az eredeti vagy az angol címet. National Security Strategy and Strategic Defence and Security Review 2015.; National Security Capability Review [online]. Cabinet Office, 2018. Forrás: assets.publishing.service.gov.uk [2019. 10. 25.] 
országai, egyéb bilaterális egyezményeken keresztül (többek között Franciaországgal) és nemzeti szinten egyaránt megvalósíthatónak látja a védelmet, ehhez komplex eszközés forrásrendszert, illetve módszereket társít. Franciaország a 2017-es Védelmi és Nemzeti Biztonsági Stratégiai Felülvizsgálatban, bár kitér a világ többi részére is, a hangsúlyt Európára és a Száhel-övezetre helyezi. Az európai védelempolitika mélyítéséhez definiálja a stratégiai autonómia fogalmát: „önálló döntési és cselekvési képesség az érdekek védelmében" ${ }^{11}$ Konkrét ambíciószintet nem határoz meg, viszont kitér a hadsereg felépítésére, fejlesztési lehetőségeire, az ehhez kapcsolódó eszközökre és végrehajtási háttérre, illetve külön törvényben határoz a forrásokról (Katonai tervezési törvény 2019-2025). ${ }^{12}$

\section{Stratégák}

Stratégaként jelenik meg a 2015-ös Fehér Könyve alapján Olaszország, amely a korábbi ECFR-elemzésben elavult (2005-ös) stratégiája miatt sodródónak minősült. Az euroatlanti és euromediterrán térségre helyezve a hangsúlyt, azonban az egész világra kiterjedően elemzi a fenyegetéseket. Részletesen áttekinti a haderejét, eszközökkel és módszerekkel együtt határoz meg célokat és részcélokat. ${ }^{13}$ Átfogó végrehajtási rendszeréhez, ahogyan Franciaországnál is, bizonyos időközönként külön törvény rendelkezik a védelmi költségvetésről és felhasználásáról (Többéves védelmi tervezési dokumentum a 2017-2019 közötti hároméves időszakra). ${ }^{14}$

A de France - Witney elemzés nem határoz meg külön definíciót a nagy stratégákra és a stratégákra, viszont a besorolásnál elkülöníti a két kategóriát. A félszigeten fekvő államot abból az okból kifolyólag nem soroltam be nagy stratégaként, mivel Franciaországgal és az Egyesült Királysággal ellentétben saját globális szerepének lehetőségeire kisebb hangsúlyt fektet.

\section{Globalisták}

A globalisták közé tartozik az átfogó és egész világra kierjedő áttekintéssel, ámde töredékes cél - eszköz - forrás - végrehajtási rendszerű 2012-es magyar Nemzeti Katonai Stratégia. ${ }^{15}$ Írország semleges államként is rendelkezik Fehér Könyvvel, amely vázlatosan tartalmaz egy globális kitekintést, elemez fenyegetéseket, saját hadseregének műveleti feladatait is analizálja, viszont elsősorban a védelem civil eszközeire helyezi a hangsúlyt. ${ }^{16}$ A 2016-os német Fehér Könyv is egy Európára koncentráló, de globális kitekintéssel is rendelkező képre épít, amelyben a müveleti szint és a végrehajtás részletes, ellenben a stratégiai célok

11 Defence and National Security Strategic Review 2017. [online], République Française, 54. Forrás: defense.gouv.fr [2019. 11. 09.]

12 Loi de programmation militaire 2019-2025. [online], Ministére Des Armées, 2018. Forrás: defense.gouvr.fr [2019. 11. 09]

13 White Paper for International Security and Defence. [online], The Ministry of Defence, 2015. Forrás: difesa.it [2019. 11.09.]

14 Documento programmatico pluriennale per la Difesa per il triennio 2017-2019. [online]. Camera dei deputati Servizio Studi, 2017. 09. 12. Forrás: difesa.it [2019. 11.09.]

15 Csiki (2014) i. m. 60.; Magyarország Nemzeti Katonai Stratégiája. [online], Honvédelmi Minisztérium, 2012. Forrás: 2010-2014.kormany.hu [2019. 11. 02.]

16 White Paper on Defence. [online], Government of Ireland, 2015. Forrás: assets.gov.ie/ [2019. 11. 12.] 
csak vázlatosan jelennek meg. ${ }^{17}$ Az ugyanebben az évben megjelent szlovák Fehér Könyv a korábbinál sokkal átfogóbb biztonságértelmezése mellett részletezi a nemzetközi együttműködési formákat, műveleti és képességbeli áttekintést ad a szlovák hadseregről, amelyet kiterjedt forrás- és eszközrendszerrel támaszt alá. ${ }^{18}$ A 2017 -es spanyol Nemzeti Biztonsági Stratégiának - bár hiányzik a saját katonai képességek áttekintése, illetve a műveleti célok vázlatosak - átfogó biztonságértelmezése van, regionális megközelítés alapján és fenyegetések szerint tipizálva elemez, illetve szerepelnek célok és részcélok, és a végrehajtás módját is részletesen kifejti. ${ }^{19}$ Horvátország 2017-es védelmi dokumentuma szintén egy átfogó biztonsági áttekintéssel, vázlatos stratégiai célokkal rendelkezik, részben nevesítve eszközöket és a végrehajtás módjait, ellenben a források hiányoznak. ${ }^{20}$ Dánia 2018-as Külés Biztonságpolitikai Stratégiájában a geopolitikai kitekintés felé orientálódott, ami mellett a hadsereg definiált ambíciószintje, képességei, fejlesztések egyaránt megjelennek, alátámasztva eszközökkel és forrásokkal (ellenben a megvalósítás módja töredékes). ${ }^{21}$

\section{Lokalisták}

Csoportosításomban a lokalisták közé tartozik a legtöbb tagállam - ez a tendencia már a 2013-as elemzésben is megjelent. A balti államok Oroszország jelentette lehetséges kockázatokkal számolva elsősorban a saját térségükre koncentrálnak. A NATO (illetve Észtország és Litvánia esetében emellett az EU) keretei közötti együttműködés mellett nagy hangsúlyt kap az Egyesült Államokkal, a többi balti állammal és Lengyelországgal való védelmi kooperáció. Észtországnak 2011 óta nincs új védelmi stratégiája, kizárólag egy katonai képességfejlesztési tervet adtak ki azóta, a 2026-os évvel bezárólag, így az állam esetében az említett tanulmányt ${ }^{22}$ vettem alapul a besorolásnál. Lettország 2016-ban, Litvánia 2017-ben frissítette a stratégiai dokumentumait, viszont lényeges változás a haderő képességein (és Litvánia esetében a definiált ambíciószintjén) kívül nem történt. ${ }^{23}$ Finnország bár semleges, és elsősorban nemzeti alapon képzeli a területvédelmet a balti térségre helyezve a hangsúlyt, a NATO-val és más államokkal akár katonai együttműködést is megvalósíthatónak tart. Különös szerepet kap a hazai védelmi ipar fejlesztése, és politikai-katonai ambíciószintet is meghatároz, a szükséges eszköz - forrás - végrehajtás rendszerében..$^{24}$ Svédország esete azért érdekes, mert a 2013-as elemzésben „nagy stratégaként” jelent meg, és bár a 2017-es Nemzeti Biztonsági Stratégiában is említik a „globális biztonság”

\footnotetext{
White Paper on German Security Policy and the Future of the Bundeswehr. [online], Federal Ministry of Defence, 2016. Forrás: issat.dcaf.ch [2019. 11. 08.]

18 White Paper on Defence of the Slovak Republic. [online], Ministry of Defence of the Slovak Republic, 2016. Forrás: mosr. sk [2019. 10.31.]

19 National Security Strategy 2017. [online], Government of Spain, 2017. Forrás: dsn.gob.es [2019. 10. 04.]

20 The Republic of Croatia National Security Strategy. [online], 2017. Forrás: morh.hr [2019. 11. 12.]

21 Foreign and Security Policy Strategy 2019-2020. The Danish Government, 2018. Forrás: um.dk [2019. 11. 04.]

22 Csiki (2014) i. m.

23 National Security Strategy of the Republic of Lithuania. [online], Ministry of National Defence of the Republic of Lithuania, 2017. Forrás: kam.lt [2019. 11. 08.]; The National Defence Concept. [online], Cabinet of Ministers Riga, Saeima, 2016. Forrás: mepoforum.sk [2019. 11. 09.]

24 Securing the Finnish Defence Technological and Industrial Base. [online], Ministry of Defence, 2016. Forrás: defmin. fi [2019. 10. 20.]; Government's Defence Report. [online], Prime Ministers's Office, Helsinki, 2017. Forrás: defmin.fi [2019. 10. 20.]
} 
kifejezést, a skandináv-balti térséget elemzi, és a NATO-partnerség mellett a régió államaival történő együttmüködés a hangsúlyos. Mivel az ország semleges, részletesen megjelenik a civil védelem (nemzetközi műveletekben is), illetve a béke és biztonság promotálása a demokrácia, emberi jogok, nemek közti egyenlőség stb. tekintetében. ${ }^{25}$ Lengyelország a régiót központba helyezve stratégiai célokat határoz meg és fejt ki, emellett az átfogó megközelítés (comprehensive approach) jegyében a védelmi képességek fejlesztését összhangba hozza a társadalmi, gazdasági potenciál kihasználásával, a puha és kemény hatalmi eszközök szinkronizálásával - mindehhez eszközöket és forrásokat részben, megvalósítási módokat részletesen definiálva. ${ }^{26}$ Portugália szintén lokális szinten gondolkozik, bár megemlít globális biztonságpolitikai kihívásokat a 2015-ös Védelmi Könyv 2020 és a 2018-as Védelmi Irányelv is. Elsősorban a saját haderejének képesség- és szervezeti fejlesztésére (Defesa 2020 program) koncentrál, műveleti szinten gondolkozik, illetve a NATO-, EU- és ENSZelvárásoknak való megfelelést emeli ki. ${ }^{27}$ A 2016-os román Katonai Stratégia az euroatlanti térség fenyegetéseit elemzi, és bár stratégiai és müveleti célok egyaránt vannak a dokumentumban, az utóbbit fejti ki részletesen. A hadsereg felépítését haderőnemek szerint elemzi, és bár a végrehajtás kifejtése hiányos, a források azonosítása széles körü. ${ }^{28}$ Szlovénia a korábbi stratégiájától eltérően a lokalista felfogás felé csúszott el - a 2016-os Stratégiai Védelmi Felülvizsgálatban saját központi szerepére koncentrál a Nyugat-Balkánon, illetve vázlatosan definiált ambíciószinttel és képességfejlesztési programmal rendelkezik. ${ }^{29}$ Bulgária szintén a régióra helyezve a hangsúlyt fogalmaz meg stratégiai irányelveket, politikai ambíciókat a védelemben, és részletes a hadsereg müveleti célkitűzéseinek elemzése. ${ }^{30}$ A Cseh Köztársaság, bár 2013-ban még stratégaként jelent meg, a 2017-es védelmi dokumentumában már kevésbé hangsúlyos globális kitekintéssel a közép-európai térségre koncentrál. A politikai és katonai ambíciószint mellett hangsúlyt helyez a NATO fontosságára és a civil kötelességekre - forráseszköz és végrehajtási rendszere részletes. ${ }^{31}$ Luxemburg nem rendelkezik Fehér Könyvvel vagy stratégiával, mindössze 2017-ben egy Védelmi Irányelvek 2025+ címü dokumentumot fogadtak el. Viszont mivel az irat transzatlanti, azon belül európai súlyponttal elemzi a stratégiai célokat, illetve a müveleti szintü megvalósítást, jelen esetben stratégiaként kezelem. A hangsúly a végrehajtáson, a szakpolitikai módszereken van, forrásokkal alátámasztva. ${ }^{32}$ Hollandia 2018-as védelmi kiadványaiban a térséget átfogó fenyegetéselemzéssel tekinti át, és három fő pilléren keresztül (megelőzés, védelem,

25 National Security Strategy. [online], Government Offices of Sweden, 2017. Forrás: government.se [2019. 10. 15.]

26 National Security Strategy of the Republic of Poland. [online], Warsaw, National Security Bureau, 2014. Forrás: bbn.gov. pl [2019. 11. 09.]

27 Defesa 2020. Governo de Portugal, 2015.; Diretiva Estratégica 2018-2021. [online], Estado-Maior-General das Forças, 2018. Forrás: operacional.pt [2019. 10. 04.]

28 The Military Strategy of Romania. [online], Ministry of National Defence, 2016. Forrás: eda.europa.eu [2019. 11. 09.]

29 Increasing Slovenia's defence capacity. [online], Strategic Defence Review, 2016. Forrás: mepoforum.sk [2019. 11. 10.]

30 Programme for the Development of the Defence Capabilities of the Bulgarian Armed Forces 2020. [online], Council of Ministers of the Republic of Bulgaria, 2015. Forrás: strategy.bg [2019. 10. 30.]

31 The Defence Strategy of the Czech Republic. [online], Ministry of Defence of the Czech Republic, Prague, 2017. Forrás: army.cz [2019. 10.31.]

32 Luxembourg Defence Guidelines for 2025 and Beyond. [online], Ministry of Foreign and European Affairs, Defence Directorate, 2017. Forrás: defense.gouvernement.lu [2019. 11. 10.] 
erősítés) 13 kisebb részcélt határoz meg, amelyek megvalósítási módja viszont hiányos. Ambíciószintet nem definiál, mivel a fogalmat irrelevánsnak tekinti. ${ }^{33}$

\section{Kimaradók}

A kimaradók közé két tagállamot soroltam: Ausztriát és Máltát. A semleges Ausztria a 2013-as Biztonsági Stratégiájában csak Európára kitérve említ együttmüködési formákat az EU, ENSZ, EBESZ és Európa Tanács keretei között, a NATO-val a Békepartnerség program keretében müködik együtt, viszont a hangsúly a civil képességek erősítésén, a kibervédelmen és a nemzeti alapú védelmen van. ${ }^{34}$ Málta igen kompakt - mindössze nyolcoldalas - stratégiai dokumentummal rendelkezik a 2016-2026 közti haderöfejlesztési tervekkel kapcsolatban, amelyben hiányzik a cél - eszköz - forrásrendszer és a fenyegetések elemzése, ${ }^{35}$ ezért esetében ezt nem értelmezhetjük konkrét stratégiának, ellentétben Luxemburg komplex irányelveivel.

\section{Sodródók}

Sodródóként jelenik meg Görögország, mivel stratégiai prioritásai a területvédelmen, a nemzeti szuverenitás és integritás fizikai védelmén alapulnak - a Törökországgal való konfliktusra és a közvetlen szomszédságára koncentrálva, bár részt vesz missziókban (például KFOR) nem hangsúlyos az európai országoknál általánosan látható többnemzeti, szövetségi beágyazottság. ${ }^{36}$ Görögországhoz szorosan kapcsolódik Ciprus kérdése, amely mindössze egy kiberbiztonsági stratégiával rendelkezik. Emellett idesorolom Belgiumot - az ország stratégiai dokumentuma 2016-os, viszont a haderő felépítése az egyetlen rész, ahol saját érdekeket definiál, a kiadvány többi részében fóként az Unió, kisebb mértékben a NATO szempontjait ismétli. ${ }^{37}$

\section{Együttmúködési kultúrák}

Az ECFR 2018-as Coalition Explorer című kiadványa alapján három szempont szerint vizsgáltam meg a tagállamokat. Megnéztem, milyen mértékben tekintik prioritásnak a közös védelmi struktúra kialakítását, mely tagállamokkal müködnének együtt, illetve a korábban említett együttmüködési formációk közül (uniós keretek között, külön szerződéses alapon, ad hoc koalíciókban vagy nemzeti alapon) melyiket látják megvalósíthatónak.

\footnotetext{
33 Defence White Paper 2018. Investing in Our People, Capabilities and Visibility. [online], Ministry of Defence, 2018. Forrás: english.defensie.nl [2019. 11. 01.]; Working Worldwide for the Security of the Netherlands. An Integrated International Security Strategy 2018-2022. [online], Ministry of Foreign Affairs, 2018. Forrás: government.nl [2019. 11. 01.]

34 Austrian Security Strategy. Security in a new decade - Shaping security. [online], Bundesministerium für europäische und internationale Angelegenheiten, Vienna, 2013. Forrás: bundesheer.at [2019. 10. 04.]

35 The Armed Forces of Malta. Strategy Paper 2016-2026. [online], Press Brief, 2017. Forrás: homeaffairs.gov.mt [2019. 10. 07.]

36 Spyros Economides: Greece. In Biehl-Giegerich-Jonas (2013) i. m. 153-164. 163.

37 The Strategic Vision for Defence. [online], Belgian Ministry of Defence, 2016. Forrás: cyberwar.ro [2019. 10. 30.]
} 
Először az első két aspektust elemzem összevetve. Prioritásként definiálom a közös védelmi struktúra kialakítását minden olyan ország tekintetében, amely a kérdést az említett véleménykutatásban a nyolc legfontosabb uniós szakpolitika közé sorolta ${ }^{38}$ - ennek oka, hogy az elemzés csak ezen államok preferenciáira tér ki. Idetartozik a 28 tagállamból 16, kivéve Horvátországot, Dániát, Írországot, Máltát, Portugáliát, Szlovéniát, Lengyelországot, Nagy-Britanniát, Svédországot, Észtországot, Hollandiát és Ausztriát. A közös európai védelem kialakításában kiemelten érdekelt és a szükséges katonai képességekkel is rendelkező Franciaország és Németország áll a koalíciós preferenciák központjában, mivel minden, a kérdést prioritásként értékelő tagállam fontos partnerként nevezte meg őket. Emellett kiemelendő még Olaszország és Spanyolország (10 és 9 szavazattal, köztük Franciaország és Németország támogatásával), amely országok szükséges katonai képességei fejlesztés alatt állnak.

Jól elkülöníthetők a területi alapú preferenciák - ezeket különböző gráfokon ábrázoltam, és minden gráfon csak az aktuálisan elemzett tagállamok érdekei látszódnak. A könnyebb átláthatóság érdekében az országneveket az ISO 3166 Alpha-2 kód alapján írtam. Zöld vonallal kötöttem össze a tagállamok közötti kölcsönös védelmi koalíciós igényt, a sárga nyíl csak azon ország részéről mutat együttműködési szándékot, ahonnan kiindul a nyíl, illetve a lila szín esetében olyan tagállam felé irányul a preferencia, amely nem sorolta a legfontosabb nyolc uniós szakpolitika közé a közös védelmi struktúra kialakítását.

Nyugat-Európában (2. ábra) a fentebb említetteken kívül megfigyelhető Belgium és Luxemburg kooperációs szándéka. Belgium és Németország között közös akarat van a védelmi együttmúködésre, emellett az ország a négy központi tagállamon kívül NagyBritanniával és Lengyelországgal szeretne összefogni. Luxemburgnak pedig (szintén a fenti négy állam mellett) Belgium, Hollandia és Svédország lenne a preferált koalíciós partner.

A Baltikumban és Skandináviában (3. ábra) Finnország, Litvánia és Lettország együttmüködési hajlandóságát vizsgálom, amelyek egyrészt egymással (Litvánia Lettországgal és Finnországgal, Lettország Finnországgal), illetve Észtországgal (Finnország és Lettország), Svédországgal (Finnország és Lettország), Dániával (Litvánia) és Lengyelországgal (Lettország és Litvánia) szeretnének kooperálni. Nem a térséghez tartozik, viszont még Hollandia emelhető ki a Baltikum esetében, mivel Finnország és Lettország is lehetséges szövetségesként jelölte meg. Emellett természetesen az Unió központi országai (Franciaország, Németország, Nagy-Britannia) egyaránt megjelennek.

38 Q12: „Melyik politikai projekt bír a legnagyobb prioritással az Ön kormánya számára? Mely országokkal preferálnák a prioritások tekintetében az együttműködést?” (Szerzői fordítás. „What policy projects have the highest priority for your country's government? Which countries are favoured partners for cooperating on these priorities?"); EU Coalition Explorer - Results of the EU28 Survey 2018 on coalition building in the European Union. [online], 2018. 906. Forrás: ecfr. eu [2019. 10. 12.] 


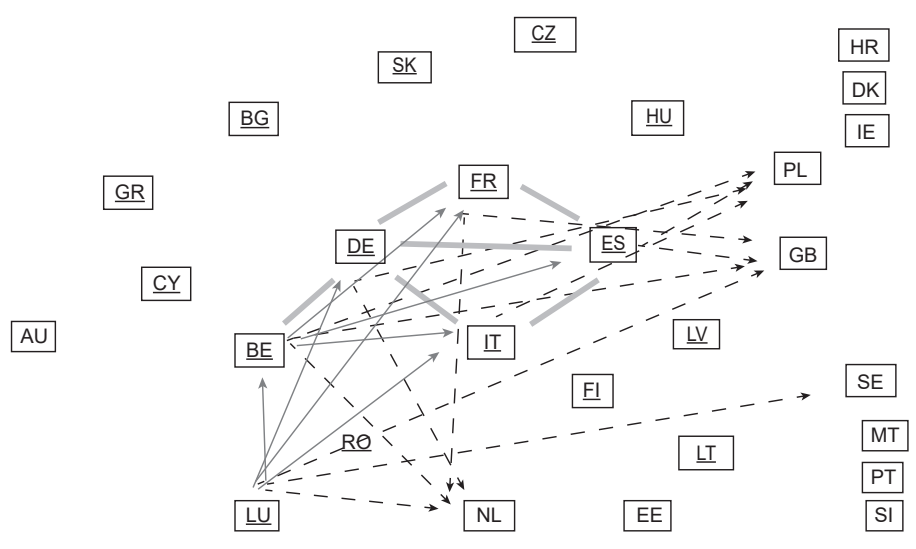

2. ábra: Együttmüködési preferenciák az EU-tagállamok körében, Nyugat-Európa

Forrás: a szerző szerkesztése az EU Coalition Explorer (2018) i. m. adatai alapján

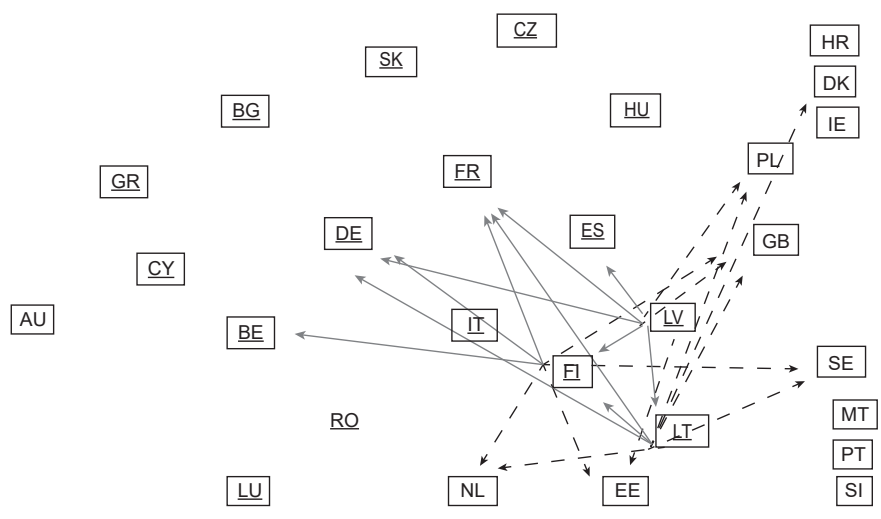

\section{3. ábra: Együttmüködési preferenciák az EU-tagállamok körében, Észak-Európa}

Forrás: a szerző szerkesztése az EU Coalition Explorer (2018) i. m. adatai alapján

Kelet-Közép-Európában (4. ábra) a Visegrádi Négyek közti lehetséges védelmi együttműködés kérdése olyan módon jelenik meg, hogy Magyarország és Csehország között, illetve Csehország és Szlovákia között figyelhető meg kölcsönös együttmüködési szándék. Bár Magyarország hajlandó lenne Szlovákiával is kooperálni, az elemzés szerint visszafelé ez a szándék hiányzik. Emellett Lengyelországgal mind a három állam szeretne egy koalícióban lenni. Érdekes, hogy Magyarország még Romániát nevezte meg, illetve Szlovákiával együtt a semleges Ausztriát. 


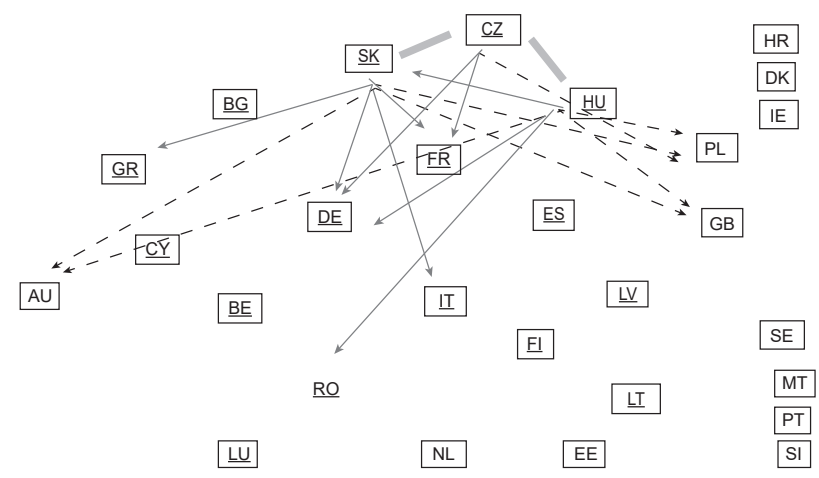

\section{4. ábra: Együttmüködési preferenciák az EU-tagállamok körében, Visegrádi Négyek}

Forrás: a szerző szerkesztése az EU Coalition Explorer (2018) i. m. adatai alapján

A Balkánon (5. ábra) a területi konfliktus miatt és ebből következően kiemelten a görög ciprióták léte az oka, hogy Görögország és Ciprus közösen képzelik el a védelmi együttmüködést. Bár Bulgária és Szlovákia megvalósíthatónak látják a kooperációt Görögországgal, a tagállam Cipruson kívül csak nyugat-európai országokat nevezett meg (Franciaország, Németország, Spanyolország, Olaszország). Emellett Bulgária még Romániát emelte ki potenciális szövetségesként, amely a Görögország által preferált államok mellett (Cipruson kívül) még Belgiummal fejezte ki együttmüködési szándékát.

Az ebben az esetben kimaradónak definiált országok közül ki kell emelnünk Hollandiát, Lengyelországot és Nagy-Britanniát, mivel mind a három állam legalább két földrajzi térség országai által preferált partner lenne (6. ábra). Hollandiát a nyugat-európai (Franciaország, Németország, Belgium, Luxemburg), illetve az észak-európai államok (Finnország, Lettország) egyaránt megjelölték, míg Lengyelországot a 16 tagországból 11 tüntette fel lehetséges védelmi szövetségesnek (beleértve Kelet-Közép-, Nyugat-, Észak- és DélEurópát egyaránt). Nagy-Britanniát pedig Németországon, Olaszországon, Csehországon és Cipruson kívül minden állam preferálná. Ezért, ha egy későbbi közös stratégiai kultúra kialakításáról beszélünk, figyelembe kell vennünk ezen országok érdekeit is.

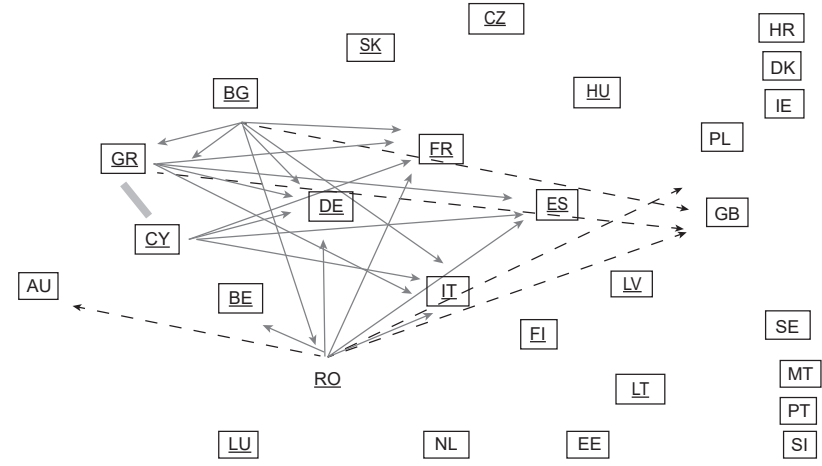

5. ábra: Együttmüködési preferenciák az EU-tagállamok körében, Balkán

Forrás: a szerző szerkesztése az EU Coalition Explorer (2018) i. m. adatai alapján 


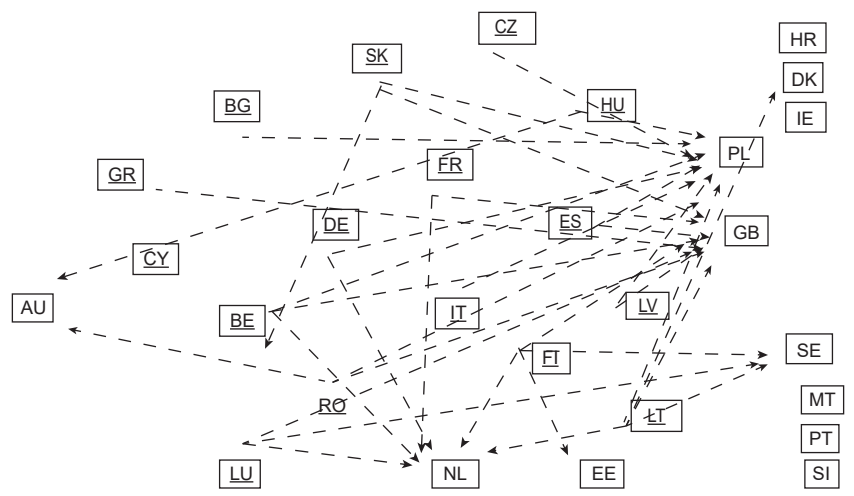

6. ábra: Együttmüködési preferenciák azon EU-s tagállamok irányába, amelyek nem tekintik prioritásnak a kérdést

Forrás: a szerző szerkesztése az EU Coalition Explorer (2018) i. m. adatai alapján

A védelmi struktúra kialakításának preferált módját az alapján csoportosítottam, hogy a megadott kérdésre („Milyen döntéshozatali szintet részesítene előnyben az Ön kormánya a következő európai politikai projektekben?"39; illetve a közvéleménykutatás esetében: „Az EU-n belül, kinek kellene felelősnek lennie a következő politikai projektekben?”40) a négy lehetőség közül arányában melyiket választották a válaszadók. Ez bizonyos tagállamoknál megoszlik két, elenyésző esetben kettőnél több opció között, amit az elemzésben szintén figyelembe veszek. Bizonyos országoknál tisztán látszik, melyik kooperációs módot preferálnák, először ezeket tekintem át. Az adatok elemzésénél meg kell említeni, hogy a tagállamoknál különböző számú résztvevőnek tették fel ugyanezt a kérdést, a közvélemény-kutatásnál egy 10885 fős mintából vontak le eredményeket - az eltérő számú válaszadók miatt esetleges torzulások elöfordulhatnak.

A megkérdezettek 39\%-a minden ország egységes részvételével tartja megvalósíthatónak a közös védelmi struktúrát. ${ }^{41} \mathrm{Az}$ arányszám több mint a fele Belgium esetében, amelynek ez összefügghet a sodródó stratégiai kultúrájával. A védelmi stratégiai vízió című 2016-os kiadványban az európai védelem esetében egyrészt az Unió védelmi képességeinek erősítésére helyezik a hangsúlyt, olyan értelemben, hogy saját határterületein képes legyen önálló katonai műveleteket folytatni, másrészt ezt a NATO-t kiegészítve képzelik el. ${ }^{42} \mathrm{~A}$ kimutatáson jól látszik, hogy a döntéshozók és egyéb szakértők visszajelzése (13 válaszadó) és a közvélemény-kutatás (233 válaszadó) eredménye bár nem teljesen esik egybe, hiszen a közvélemény-kutatásnál felmerül a „nemzeti alapon” opció is, az „összes tagállam részvételével" válasz aránya egyaránt kiemelkedően magas. ${ }^{43}$ Luxemburg védelmi dokumentumában hasonlóképpen kiemelték, hogy az ország elkötelezett az erős európai védelem

\footnotetext{
39 Q10 „Which level of decision-making would your government prefer for the following list of European policy projects?”; EU Coalition Explorer (2018) i. m. 742.

40 Q11 „In the EU, who should mainly be responsible for the following policy projects?”; EU Coalition Explorer (2018) i. m. 777 .

41 Jelen esetben azért használom a „védelmi struktúra” kifejezést, mert a Coalition Explorer tanulmány a védelmi együttműködést egy közös intézmény/struktúra létrehozásában definiálja, amely különböző döntéshozatali formákban valósulhatna meg.

42 The Strategic Vision for Defence (2016) i. m. 29-30.

43 EU Coalition Explorer (2018) i. m. 654., 784.
} 
mellett az EU-n és a NATO-n keresztül. ${ }^{44}$ A válaszadók több mint fele az Unión belüli védelmi integráció mélyítése mellett foglalt állást, a szakértők (13 fö) és a közvélemény (15 fö) között szintén az a különbség merül fel, hogy a közvéleménynél nemzeti alapon is el tudja képzelni a megfelelő védelmi képességek kialakítását. ${ }^{45} \mathrm{~A}$ kelet-közép-európai országok (azon belül is fóképp a déli-délkeleti csoportjának) jelentős része (Magyarország, Horvátország, Bulgária, Románia, Szlovénia, Cseh Köztársaság) szintén ebbe a kategóriába tartozik. Az említett hat tagállam esetében a stratégiák - bár kiemelik az aktív részvételt az Unió biztonság- és védelempolitikájában - nem térnek ki konkrétan az európai védelempolitika fejlődésére. Emellett a sodródó Görögország és a stratégiával nem rendelkező Ciprus is ide kapcsolódik - utóbbi esetében a legmagasabb az Unión belüli közös védelmi struktúra kialakításának támogatottsága: a 12 megkérdezett szakértőből 11 e mellett foglalt állást. ${ }^{46}$ Finnország az egyetlen olyan észak-európai tagállam, amely határozottan az öszszes tagállam részvételével látja megvalósíthatónak a kooperációt. A finn kormány 2017-es védelmi jelentésében kifejti, hogy bár a legtöbb uniós tagállam területvédelme a NATO-n alapszik, az EU az átfogó biztonság szereplője, amely „fontos szerepet játszik az európai védelmi kooperáció erősítésében" - célja, hogy képes legyen külső és belső biztonsági kihívásokat kezelni. ${ }^{47}$

Észtország, Lettország és Spanyolország esetében a döntéshozók és szakértők válaszai szerint (19, 12 és 29 megkérdezett) a preferált döntéshozói szint megoszlik az „összes tagállam részvételével” és a „szerződéses alapon” opciók között. ${ }^{48}$ Míg a közvélemény szerint a kérdés sokkal differenciáltabb, kisebb az arányszáma a „szerződéses alapon” lehetőségnek, és az „informális csoport”, illetve a „nemzeti alapon” egyaránt releváns. ${ }^{49}$ Szlovákia, amelynél az eredmények szintén fragmentáltak (nagyrészt a „szerződéses alap” és az „öszszes tagállammal együtt" opciók között), a CSDP-ben (Common Security and Defence Policy) a képességfejlesztés terén fejezte ki kooperációs szándékát. ${ }^{50}$

A védelmi kooperáció „szerződéses alapon” történő megvalósításának legfőbb támogatói Németország, Olaszország és Portugália. Németország és Olaszország esetében, ha megnézzük a PESCO-ról (Permanent Structured Cooperation) szóló tárgyalásokat, illetve az olasz kezdeményezésű „védelmi Schengen” koncepciót, nem meglepő. Bár mindhárom tagállamnál ez a döntéshozók és szakértők álláspontja, a közvélemény-kutatásnál többségbe került a „minden tagállam részvételével” opció. ${ }^{51}$ Hollandiánál és Franciaországnál (utóbbinál a 2018-as Európai Intervenciós Kezdeményezés jó példája ennek) a megkérdezett döntéshozók és szakértők többségi véleménye megoszlik a „szerződéses alapú” és az „informális csoport” között - ez szintén különbözik a közvéleménynél, amelynél viszont az összes tagállam részvételét preferálják. ${ }^{52}$

\footnotetext{
4 Luxembourg Defence Guidelines for 2025 and Beyond (2017) i. m. 18.

EU Coalition Explorer (2018) i. m. 671. és 800.

EU Coalition Explorer (2018) i. m. 658.

Government's Defence Report (2017) i. m. 8.

EU Coalition Explorer (2018) i. m. 661., 669., 679.

EU Coalition Explorer (2018) i. m. 790., 798., 808.

White Paper on Defence of the Slovak Republic (2016) i. m. 42.

EU Coalition Explorer (2018) i. m. 664., 668., 675., 793., 797., 804.

EU Coalition Explorer (2018) i. m. 663., 673., 792., 802.
} 
Az Egyesült Királyság szakértői által adott vélemények (21) többségében azt szeretnék, hogy a védelem nemzeti alapon maradjon, viszont mivel az ország csatlakozott az EI2 szándéknyilatkozatához, a védelmi informális csoportban való részvétel preferenciájának aránya is magas. Azonban a közvélemény-kutatásban (1462 fö) még a Brexit után is jelentős maradt azok aránya, akik az Unión belül tartják fontosnak a megvalósítást. ${ }^{53} \mathrm{~A}$ védelem nemzeti keretek között tartása mellett foglal állást Málta is - bár ez szintén csak a szakértők szerint lenne jó így, a közvélemény elképzelhetőnek tartja az Unión belül is. ${ }^{54}$

Mindemellett van öt olyan állam, amelyeknél nem lehet konkrétan kijelenteni, hogy melyik formát látja megvalósíthatónak, mivel a vélemények hasonló arányban oszlanak meg a négy választási lehetőség között: a semleges Ausztria, Svédország és Írország, a CSDP-ben opt-outtal rendelkező Dánia, illetve Lengyelország, amely alapvetően az Egyesült Államok támogatását tartja szükségesnek az európai védelemben.

A felvázolt preferenciák alapján kijelenthetjük, hogy a nemzeti stratégiai kultúra és az elképzelhetőnek tartott védelmi döntéshozatali szint között nincs közvetlen összefüggés, hiszen a stratégák, lokalisták, globalisták, kimaradók és sodródók között is vannak olyanok, akik az összes tagállam részvétele, és akik más formációk mellett foglalnak állást. Többségében a közvéleménynél az Unión belüli megvalósítás nagyobb arányban van jelen az államokban, mint a szakértőknél, de a másik véglet, a nemzeti alapon maradás is gyakoribb.

Másrészt közvetlen összefüggést a preferált döntéshozatali szint és a koalíciós partner között sem találtam - ha megnézzük például a többségében minden tagállam részvételét előnyben részesítő országokat, tehát Belgiumot, Bulgáriát, Horvátországot, Ciprust, Finnországot, Görögországot, Magyarországot, Luxemburgot, Romániát és Szlovéniát, láthatjuk, hogy szerepelnek köztük olyan partnerek, akiknek érdeke lenne egymással védelmi alapon kooperálni (Görögország és Ciprus) vagy legalább az egyik félnek (többek között Belgiummal Luxemburgnak, Finnországnak, Romániának), összességében nincs ilyen alapú kapcsolat minden érintett állam között. Ugyanez megfigyelhető a preferált koalíciós partnerek és a stratégiai kultúra között.

\section{Stratégiai autonómia}

A stratégiai autonómia olyan fogalom, amelynek meghatározása és megvalósítási módja is vitatott. Alapvetően három fajtáját különböztethetjük meg a tagállamok nézőpontja szerint: döntéshozatali autonómia, cselekvési autonómia és információs autonómia. Az első a politikai akaratra és a döntéshozatali folyamatra helyezi a hangsúlyt, a második a katonai és civil képességek és a műveleti készenlét fejlesztésére, a harmadik pedig a hírszerzésre, elemzésekre és adatgyüjtésekre. ${ }^{55}$ Egy másik fajta definíció, hogy a stratégiai autonómia jelenthet függetlenséget más hatalmaktól, illetve képességet arra, hogy önállóan müveleteket valósítson meg az adott állam (vagy éppen mindkettőt). ${ }^{56} \mathrm{Az}$ európai stratégiai autonómia

\footnotetext{
EU Coalition Explorer (2018) i. m. 681., 810

EU Coalition Explorer (2018) i. m. 672., 801.

Franke-Varma (2018) i. m. 6.

Franke-Varma (2018) i. m. 3.
} 
(ESA) eléréséhez szükséges egyrészt definiálni magát a fogalmat, másrészt a politikai akaraton kívül kell egy közös földrajzi és funkcionális ambíciószint, közös stratégiai kultúra, valamint meg kell határozni a közös képességfejlesztési területeket (ezen belül meg kell oldani olyan kérdéseket, mint hogy beletartozna-e a nukleáris elrettentés az ESA-ba), illetve a NATO-hoz és föképp az Egyesült Államokhoz füződő viszonyt. ${ }^{57}$ Ezen szempontok alapján fogom áttekinteni, hogy viszonyulnak a tagállamok a stratégiai autonómia megvalósításához (kivéve a stratégiai kultúrát, amelyre a második fejezetben már kitértem). A kérdést a bevezetésben említett Franke - Varma: Independence Play: Europe's Pursuit of Strategic Autonomy címü 2019-es ECFR-elemzés adatai alapján elemzem.

Először is fontos megvizsgálni, hogy a tagállamok szerint milyen fajta autonómiát lenne szükséges az Uniónak kialakítania. Az Egyesült Királyság, Németország, Lengyelország, Portugália, Belgium, Luxemburg és Szlovákia szerint a döntéshozatali önállóságot kellene erősítenie, Franciaország, Hollandia, Dánia, Finnország, Lettország, Litvánia, Svédország, Bulgária, Csehország és Románia a cselekvési autonómia mellett foglal állást, illetve Ausztria, Horvátország, Málta, Ciprus és Észtország az információs autonómiát preferálná. A további hat tagállam (Írország, Spanyolország, Olaszország, Szlovénia, Magyarország és Görögország) a véleménykutatás szerint eltérő módon képzeli el a megvalósítást: ${ }^{58}$ Görögország az ESA-t egyfajta PESCO-hoz hasonló képességekkel kapcsolatos projektekben és közös csapattelepítésekben látja; Magyarország kivárja a közös uniós álláspont kialakítását; Írországban a kérdésről csak tudományos körökben vannak viták, semlegessége miatt nincs konkrét állásfoglalás; Olaszország ESA-koncepciója a saját nemzeti érdekeik és az európai prioritások egymást kiegészítő jellegére korlátozódik; ${ }^{59}$ Szlovénia a fogalmat úgy értelmezi, mint az Unió nagyobb mértékü hozzájárulása a NATO-hoz, hatékonyabb döntéshozatallal és képességfejlesztéssel; Spanyolország számára pedig az ESA túlmutat a katonai kérdéseken, és magában foglalja az EU gazdasági érdekeinek védelmét, a civil képességeket és a technológiai innovációt egyaránt. ${ }^{60}$

Azt, hogy mennyire tartják az országok prioritásnak a stratégiai autonómia kiépítését a saját maguk által preferált módon, már a korábbi, 2018-as Coalition Explorer elemzésböl is kitünik, viszont a jelenleg vizsgált 2019-es ECFR-elemzés árnyalja a képet, és „fontos”, „Valamennyire fontos”, „nem túl fontos”, „ellenzi” kategóriákba osztotta a tagállamokat. A két elemzés között az eltérés abban mutatkozik meg, hogy a 2019-es Franke - Varma kutatás Magyarországot is a „nem túl fontos” kategóriába sorolja, illetve Portugália, Ausztria, Szlovénia, Horvátország tekintetében a „valamennyire fontos” opciót választja. ${ }^{61}$ A különbség oka lehet az eltérö kérdésfeltevés is, hiszen a 2018-as Coalition Explorerben az összes szakpolitikához viszonyítva rangsoroltak a döntéshozók és a szakértők, a 2019-es elemzésben pedig külön értékelték kizárólag az ESA fontosságát.

A földrajzi és funkcionális ambíciószint esetében elmondhatjuk, hogy van közös álláspont. A territoriális ambíciószintnek 24 tagállam az Unió szomszédságát definiálja,

\footnotetext{
Franke-Varma (2018) i. m. 1.

Franke-Varma (2018) i. m. 15.

Franke-Varma (2018) i. m. 27-30.

Franke-Varma (2018) i. m. 40-41.

61 Franke-Varma (2018) i. m. 2.
} 
ideértve Kelet-Európát, a Közel-Keletet és Észak-Afrikát, ami megfelel a 2016-os Globális Stratégiának: „a hazai biztonságunkkal együtt jár az érdekeltség a szomszédságunkban és a környező régiókban lévő békével". ${ }^{62} \mathrm{Nem}$ emellett foglalt állást Olaszország és Románia, amelyeknek szélesebb térségben van érdekeltsége (tehát a déli és keleti szomszédság mellett a szubszaharai Afrikát is beleértve), illetve Görögország és Lettország, amelyek a területi védelemre helyeznék a hangsúlyt. Az Egyesült Királyság és Észtország szerint az ESA a globális ambíciószintet is elérheti, és 14 tagállam beleérti az ESA kiterjedésébe a világürt és a kiberteret is. ${ }^{63}$ Utóbbi azért is lehet releváns, mert bár Európa 1975 óta rendelkezik űrügynökséggel, az Unió 2016-ban adott ki egy ürstratégiát, illetve az űrkutatás integráns része a Horizon 2020 programnak, ${ }^{64}$ a kibertérről pedig elöször 2016-ban tárgyaltak az igazságügy-miniszterek szintjén, és 2019 áprilisában fogadták el a szakpolitikai keretét (Cybersecurity Act), ami szervezetileg és jogilag is változtatásokat eszközöl, többek között létrehozva az Európai Uniós Kiberbiztonsági Ügynökséget. Emellett 2019 májusától kezdve a Tanács megkísérelt és megvalósult kibertámadásokért egyaránt szankciókat vethet ki. ${ }^{65}$

A műveleti ambíciószint esetében a Globális Stratégia (GS) kijelöli, hogy az Uniónak a konfliktus eszkalálódásának minden szintjén cselekedni kell tudnia a jövőben, a válságmegelőzés, -kezelés és békeépítés területén egyaránt ${ }^{66} \mathrm{~A}$ véleménykutatás szerint a tagállami nézőpont nem minden esetben egyezik meg ezzel: öt ország kivételével (Románia, Horvátország, Magyarország, Málta és Olaszország) minden tagállam beleérti a műveleti ambíciószintbe a konfliktus utáni stabilizációt; Bulgárián, Észtországon, Lettországon, Románián és Olaszországon kívül a többi állam szerint idetartozik a válságkezelés is. ${ }^{67}$ Érdekes, hogy míg a GS a kollektív biztonság felé mozdítaná el az Uniót ${ }^{68}$ nyolc ország (Ciprus, Finnország, Luxemburg, Ausztria, Bulgária, Észtország, Lettország és Olaszország) az alapvetően a NATO-hoz tartozó kollektív védelmet képzeli el az ESA részeként. ${ }^{69}$

A képességfejlesztés területén a felmérés szerint a nemzeti szakértők a következő képességeket tartják fontosnak az ESA kiépítésében: „légi utántöltés, civil képességek, egészségügyi támogatás és evakuáció, interoperabilitás, katonai mobilitás, drónok, illetve az EDF és PESCO projektek végrehajtása kapcsán növekvő együttmüködés". ${ }^{70}$ Az Unió 2018-as Képességfejlesztési Terve kitér az említett prioritásokra és ezenfelül a kibertérben zajló műveletek képességfejlesztésére, a világürhöz kapcsolódó információs és kommunikációs szolgáltatások modernizálására, az információs fölényre, illetve minden haderőnemhez meghatároz korszerüsítési területeket. ${ }^{71}$

\footnotetext{
62 Fordította a szerző. Shared Vision, Common Action: A Stronger Europe. [online], Brüsszel, EEAS, 2016. 14. Forrás: eeas. europa.eu [2019. 11. 10.]

63 Franke-Varma (2018) i. m. 7

64 European Commission: Horizon 2020 - Space. [online], Forrás: ec.europa.eu [2019. 07. 10.].

65 European Consilium: Kiberbiztonság Európában: szigorúbb szabályok és nagyobb védelem. [online], Forrás: www.consilium.europa.eu [2019. 11. 10.].

66 Shared Vision, Common Action: A Stronger Europe. (2016) i. m. 9.

67 Franke-Varma (2018) i. m. 8.

68 Shared Vision, Common Action: A Stronger Europe. (2016) i. m. 9.

69 Franke-Varma (2018) i. m. 8.

70 Franke-Varma (2018) i. m. 9.

${ }^{71}$ European Defence Agency: Capability Development Plan. [online], Brussels, 2018. 06. 28. Forrás: www.eda.europa.eu [2019. 11. 10.] 3 .
} 
Felmerül a kérdés, hogy a nukleáris elrettentésnek részét kellene-e képeznie az ESAnak, hiszen a nukleáris képesség birtoklása integráns részét képezné annak, hogy Európa hiteles globális szereplővé váljon. Egyedül Észtország szerint szükséges Európának nukleáris kapacitás; hat tagállam (Belgium, Németország, Olaszország, Lettország, Görögország, Ciprus) szakértői amellett foglaltak állást, hogy a francia és brit nukleáris elrettentő képességek elegendők az ESA-hoz; a nukleáris hatalmak - Franciaország és az Egyesült Királyság -, Portugália, Lettország, Finnország, Bulgária, Lengyelország, Csehország, Szlovákia, Magyarország, Horvátország, Szlovénia szerint a nukleáris elrettentés túlmutat az ESA-n; a többi állam pedig minden körülmények között problematikusnak tartja a nukleáris elrettentést. ${ }^{72}$

Az európai védelem mélyítésénél, tehát az ESA kialakításánál is kérdéses a NATO-hoz és föképp az Egyesült Államokhoz füződő viszony. Donald Trump már a 2016-os kampányában hangsúlyt fektetett „a transzatlanti biztonsági költségek aránytalan megoszlására”, kiemelve, hogy 2014-ben a walesi NATO-csúcson a tagállamok vállalták a védelmi kiadásoknak a GDP $2 \%$-ára való emelését, illetve a védelmi költségvetés $20 \%$-ának képességfejlesztésbe történő befektetését. ${ }^{73} \mathrm{Az}$ amerikai elnök 2018-as következő tweetje jól mutatja az önálló európai védelemhez való viszonyát: „Franciaország elnöke, Macron javasolta, hogy Európa építse ki a saját haderejét annak érdekében, hogy megvédje magát az Egyesült Államoktól, Kínától és Oroszországtól. Nagyon sértő, de Európának talán előbb fizetnie kellene a részét a NATO-ban, amelyet az Egyesült Államok nagymértékben támogat." ${ }^{34}$ Összességében megállapíthatjuk, hogy az Egyesült Államoknak érdeke lehet az ESA kialakítása, amennyiben az a NATO-n belül történik, elkerülve az ún. „három D”-t: a duplikációt, az elkülönülést (decoupling) az Egyesült Államoktól és a diszkriminációt a nem EU-s NATO-tagállamok ellen. ${ }^{75}$

Az említett véleménykutatás szerint 16 tagállam amellett foglal állást, hogy az ESA kompatibilis lehet a NATO-val, ha Európa betartja az említett „három D” szabályát. Franciaország, Olaszország, Spanyolország, Luxemburg, Belgium, Finnország, Horvátország és Szlovénia szerint tökéletesen kiegészítheti az ESA a NATO-t, míg Lettország véleménye alapján felmerülhetnek problémák és Észtország szükségtelennek, illetve rombolónak tartja a NATO-ra nézve. ${ }^{76} \mathrm{Az}$ Egyesült Államok aggodalmait az ESA kialakításával kapcsolatban Ciprus tartja nagyon aggasztónak, mivel az „EU nem engedheti meg magának az Egyesült Államoktól való elidegenedést”, az Egyesült Királyság, a Baltikum, Svédország, Lengyelország, Magyarország és Románia szintén komolynak tartja a problémát, mivel „az uniós döntéshozatalnak e téren gyakrabban kellene figyelembe vennie az Egyesült Államok fenntartásait". Gazdaságilag megalapozottnak ítéli az Egyesült Államok aggodalmait Németország, Spanyolország, Portugália, Ausztria és Írország, mivel

72 Franke-Varma (2018) i. m. 9.

73 Jordan Becker - Edmund J. Malesky: Yes, NATO is sharing the defense burden. Here's what we found. [online], 2016. 10. 09. Forrás: The Washington Post [2019. 11. 10.].

74 A szerző fordítása: „President Macron of France has just suggested that Europe build its own military in order to protect itself from the U.S., China and Russia. Very insulting, but perhaps Europe should first pay its fair share of NATO, which the U.S. subsidizes greatly!" Donald J. Trump tweetje. [online], 2018. 11. 09. Forrás: Twitter [2019. 11. 10.].

75 R. Stanley Sloan: NATO, the European Union, and the Atlantic Community: The Transatlantic Bargain Challenged. Rowman \& Littlefield Publishers, 2005. 191.

76 Franke-Varma (2018) i. m. 6. 
az ESA-nak erősítenie kellene az európai védelemi ipari és technológiai bázist. Ezzel szemben Franciaország, Olaszország, Szlovénia, Szlovákia, Bulgária és Málta „furcsának” minősíti az Egyesült Âllamok fenntartásait, mivel az ESA a „legjobb módja a tehermegosztás megvalósításának”. A többi állam, ideértve többek között Finnországot, Dániát, Belgiumot, „egy félreértésen alapuló” aggodalomnak tekinti. ${ }^{77}$

A fentiek alapján jól látszik, mennyire különböznek az elképzelések az ESA megvalósításáról - kijelenthető, hogy az egyes országok értelmezései és preferenciái között kevés a területi vagy stratégiai kultúrák szerinti összefüggés. Többek között Észak-Európában Svédország, Lettország, Litvánia és Finnország egyaránt a cselekvési autonómiát támogatja, viszont az ESA Egyesült Államokhoz és a NATO-hoz való kapcsolatát eltérően ítélik meg, ahogyan a nukleáris képesség szükségességét is. Az olyan területeken, amelyeken történtek előrelépések az Unióban, nagyobb egyetértés figyelhető meg - például ilyen az ambíciószint vagy a képességfejlesztés.

\section{Következtetések}

A tanulmány központi kérdése az volt, hogy létre lehet-e hozni közép- vagy hosszú távon az európai stratégiai autonómiát. Ehhez először a közös stratégiai kultúrát vizsgáltam meg: a 2013-as ECFR-kutatás az európai helyzetet „stratégiai diszharmóniaként” jellemezte. 2019-ig több ország is új Fehér Könyvet / védelmi stratégiát fogadott el, ezért fontossá vált a tagállamok újrapozicionálása. Összességében a nagy stratégák változatlanok maradtak (Egyesült Királyság és Franciaország), illetve a globalisták és a lokalisták száma párhuzamosan növekedett a stratégák, sodródók és kimaradók csökkenésével. Tehát a közös stratégiai kultúra politikai szempontja még nem valósult meg, továbbra is érvényes a „stratégiai diszharmónia" kifejezés. Gazdaságilag a 2017-ben létrehozott Európai Védelmi Alap elősegíti a közös finanszírozási mechanizmus kialakítását. A másik problémás terület a közös stratégiai kultúra katonai aspektusa, amelyben bár előrelépés volt a 2017-es, nem-végrehajtó jellegü missziókért felelős katonai parancsnoki központ, a Katonai Tervezési és Végrehajtási Szolgálat (MPCC) létrehozása. Ezzel együtt az Unió folyamatosan fejlődő, komplex (és egyben fragmentált) védelmi döntéshozatali intézményrendszerrel rendelkezik, a NATO-ban már meglévő védelmi tervezési eljárások és struktúrák hiányoznak az Unióban.

Ezt követően az együttmüködési kultúra jellemzőit tekintettem át - az eredményeken látszik, hogy a tagállamok közti védelmi kooperációs preferenciák nagymértékben területalapúak. Emellett kirajzolódik a francia-német tengely, mivel szinte minden tagállamnak érdeke lenne e két országgal az együttműködés, illetve az európai védelmi integrációt nem támogató Lengyelország és a CSDP mélyítésétől elzárkózó Egyesült Királyság is a leginkább preferált partnerek között van. A megvalósítás módja, vagyis a közös védelmi struktúra döntéshozatali szintjeinek alternatívái közül többségben van a minden tagállam részvételével zajló (39\%), tehát az Unió keretei között, illetve a külön szerződéses alapon megkötendő (35\%) formátumok preferenciája.

Franke-Varma (2018) i. m. 5. 
A harmadik részben kitértem magára az európai stratégiai autonómiára. Jelen esetben a döntéshozatali és a cselekvési autonómiát vizsgáltam, emellett kiemeltem a tagállamok e kérdésről alkotott nézőpontjait. A téma áttekintése nem teljes, ennek oka a rendelkezésre álló adatok relatíve kis mennyisége, illetve a fogalom különböző értelmezési lehetőségei. A 2016-os Globális Stratégiában meghatározottakkal összhangban a territoriális és müveleti ambíciószintben létre lehet hozni konszenzust. A képességfejlesztés prioritásai szintén harmonizálnak a frissített Képességfejlesztési terv szerinti uniós állásponttal - az utóbbi években a CARD-on, az EDF-en és a PESCO projektjein keresztül elkezdték a megvalósítást. Ellenben megosztó probléma a nukleáris elrettentés léte vagy hiánya az ESA hatékony müködéséhez, illetve a NATO-hoz, kiemelten az Egyesült Államokhoz füződő viszony. Utóbbi azért is különösen fontos, mivel a NATO 2019-es elörejelzései szerint az Egyesült Államok ebben az évben több mint kétharmadát fedezi a NATO összes védelmi kiadásának,$^{78}$ és felmerül a kérdés, hogy Washington anyagi támogatása és technológiai fejlettsége nélkül mennyire lehet hatékony az európai védelem. Amennyiben pedig a NATO-t kiegészítve valósulna meg, a „három D” elv betartása nélkül kiüresítené a transzatlanti szövetséget, betartásával pedig egy sokkal visszafogottabb védelmi integráció valósulna meg.

A jelenlegi európai védelmi helyzet mellett, figyelembe véve a tagállami véleményeket, az együttmüködési lehetőségeket, a képességeket és egyéb, fent vizsgált tényezőket, véleményem szerint az európai stratégiai autonómia kialakítására csak hosszú távon van lehetőség. Bár az utóbbi években Európa, főleg az Unió keretein belül (de az EI2 kezdeményezéssel azon kívül is) nagy előrelépést tett a közös védelempolitika irányába, hiteles védelmi szereplőként globális szinten továbbra sem képes fellépni. Az ilyen mértékű stratégiai autonómia kialakítása a jelenleg mérhető tényezők mellett függ olyan, egyelőre változó tényezőktől, mint amilyen például az Egyesült Királyság Brexit utáni védelmi szerepvállalása, az Egyesült Államok mindenkori elnökének prioritásai, vagy a tagállamok jövőbeli belpolitikai érdekei. Éppen ezért a téma kutatására a következő években is nagy figyelmet kell fordítanunk.

\section{FELHASZNÁLT IRODALOM}

Austrian Security Strategy. Security in a New Decade - Shaping Security. [online], Vienna, Bundesministerium für europäische und internationale Angelegenheiten, 2013. Forrás: bundesheer.at [2019. 10. 04.]

Becker, Jordan - Edmund J. Malesky: Yes, NATO is sharing the defense burden. Here's what we found. [online], 2016. 10. 09. Forrás: The Washington Post [2019. 11. 10.]

Biehl, Heiko - Bastian Giegerich - Alexandra Jonas: Strategic Cultures in Europe - Security and Defence Policies Across the Continent. Potsdam, Springer VS, 2013. DOI: https://doi.org/10.1007/978-3-658-01168-0

Csiki Tamás: Az új Nemzeti Katonai Stratégia a nemzetközi tapasztalatok tükrében. [online], Forrás: Nemzet és Biztonság - Biztonságpolitikai Szemle, 7. (2014), 2. 45-61. [2019. 07. 10.]

Defence and National Security Strategic Review 2017.[online], République Française, 2017. Forrás: defense.gouv. fr [2019. 11.09.]

78 A NATO-tagállamok 2019-es várható összesített védelmi kiadásai 984 milliárd amerikai dollárt tesznek ki, amelyből az Egyesült Államoké 685 milliárd dollár. NATO: Defence Expenditure of NATO Countries (2012-2019). [online], 2019. 06. Forrás: www.nato.int [2019. 11. 10.], 5., a 7. sz. grafikon adatai alapján. 
Defence White Paper 2018. Investing in Our People, Capabilities and Visibility. [online], Ministry of Defence, 2018. Forrás: english.defensie.nl [2019. 11. 01.]

De France, Olivier - Nick Witney: Europe’s strategic cacophony. [online], 2013. Forrás: ecfr.eu [2019. 07. 10.]

Defesa 2020. Governo de Portugal, 2015.

Diretiva Estratégica 2018-2021. [online], Estado-Maior-General das Forças, 2018. Forrás: operacional.pt [2019. 10. 04.]

Documento programmatico pluriennale per la Difesa per il triennio 2017-2019. [online], Camera dei deputati Servizio Studi, 2017. 09. 12. Forrás: difesa.it [2019. 11. 09.]

Economides, Spyros: Greece. In Heiko Biehl - Bastian Giegerich - Alexandra Jonas: Strategic Cultures in Europe - Security and Defence Policies Across the Continent. Potsdam, Springer VS, 2013. 153-164. DOI: https://doi.org/10.1007/978-3-658-01168-0

European Defence Agency: Capability Development Plan. [online], 2018. 06. 28. Forrás: www.eda.europa.eu [2019. 11. 10.]

EU Coalition Explorer - Results of the EU28 Survey 2018 on coalition building in the European Union. [online], 2018. Forrás: ecfr.eu [2019. 10. 12.]

European Commission: Horizon 2020 - Space. [online], Forrás: ec.europa.eu [2019. 11. 10.]

European Consilium: Kiberbiztonság Európában: szigorúbb szabályok és nagyobb védelem. [online], Forrás: www. consilium.europa.eu [2019. 11. 10.]

Foreign and Security Policy Strategy 2019-2020. [online], The Danish Government, 2018. Forrás: um.dk [2019. 11. 04.]

Franke, Ulrike - Tara Varma: Independence play: Europe's pursuit of strategic autonomy. [online], 2019. Forrás: ecfr.eu [2019. 07. 10.]

Government's Defence Report. [online], Prime Ministers's Office, Helsinki, 2017. Forrás: defmin.fi [2019. 10. 20.]

Increasing Slovenia's defence capacity. [online], Strategic Defence Review, 2016. Forrás: mepoforum.sk [2019. 11. 10.]

Loi de programmation militaire 2019-2025. [online], Ministére Des Armées, 2018. Forrás: defense.gouvr.fr [2019. 11.09.]

Luxembourg Defence Guidelines for 2025 and Beyond. [online], Ministry of Foreign and European Affairs, Defence Directorate, 2017. Forrás: defense.gouvernement.lu [2019. 11. 10.]

Magyarország Nemzeti Katonai Stratégiája. [online], Honvédelmi Minisztérium, 2012. Forrás: 2010-2014. kormany.hu [2019. 11. 02.]

National Security Capability Review. [online], Cabinet Office, 2018. Forrás: assets.publishing.service.gov.uk [2019. 10. 25.]

National Security Strategy 2017. [online], Government of Spain, 2017. Forrás: dsn.gob.es [2019. 10. 04.]

National Security Strategy and Strategic Defence Security Review 2015: A Secure and Prosperous United Kingdom. [online], Prime Minister and Command of Her Majesty, 2015. Forrás: assets.publishing.service.gov.uk [2019. 10. 25.]

National Security Strategy of the Republic of Lithuania. [online], Ministry of National Defence of the Republic of Lithuania, 2017. Forrás: kam.lt [2019. 11. 08.]

National Security Strategy of the Republic of Poland. [online], Warsaw, National Security Bureau, 2014. Forrás: bbn.gov.pl [2019. 11. 09.]

National Security Strategy. [online], Government Offices of Sweden, 2017. Forrás: government.se [2019. 10. 15.]

NATO: Defence Expenditure of NATO Countries (2012-2019). [online], 2019. 06. Forrás: www.nato.int [2019. 11. 10.]

Programme for the Development of the Defence Capabilities of the Bulgarian Armed Forces 2020. [online], Council of Ministers of the Republic of Bulgaria, 2015. Forrás: strategy.bg [2019. 10. 30.]

Securing the Finnish Defence Technological and Industrial Base. [online], Ministry of Defence, 2016. Forrás: defmin.fi [2019. 10. 20.]

Shared Vision, Common Action: A Stronger Europe. [online], Brüsszel, European External Action Service, 2016. Forrás: eeas.europa.eu [2019. 11. 10.] DOI: https://doi.org/10.2871/9875

Sloan, R. Stanley: NATO, the European Union, and the Atlantic Community: The Transatlantic Bargain Challenged. Rowman\&Littlefield Publishers, 2005.

Szegő László: A stratégiai kultúráról. [online], Hadtudomány, 23. (2013), 1. 45-54. [2019. 11. 10.] 
The Armed Forces of Malta. Strategy Paper 2016-2026. [online], Press Brief, 2017. Forrás: homeaffairs.gov.mt [2019. 10. 07.]

The Defence Strategy of the Czech Republic. [online], Ministry of Defence of the Czech Republic, Prague, 2017. Forrás: army.cz [2019. 10. 31.]

The Military Strategy of Romania. [online], Ministry of National Defence, 2016. Forrás: eda.europa.eu [2019. 11. 09.]

The National Defence Concept. [online], Cabinet of Ministers, Riga, Saeima, 2016. Forrás: mepoforum.sk [2019. 11. 09.]

The Republic of Croatia National Security Strategy. [online], 2017. Forrás: morh.hr [2019. 11. 12.]

The Strategic Vision for Defence. [online], Belgian Ministry of Defence, 2016. Forrás: cyberwar.ro [2019. 10. 30.]

White Paper for International Security and Defence. [online], The Ministry of Defence, 2015. Forrás: difesa.it [2019. 11.09.]

White Paper on Defence of the Slovak Republic. [online], Ministry of Defence of the Slovak Republic, 2016. Forrás: mosr.sk [2019. 10. 31.]

White Paper on Defence. [online], Government of Ireland, 2015. 08. Forrás: assets.gov.ie/ [2019. 11. 12.]

White Paper on German Security Policy and the Future of the Bundeswehr. [online], Federal Ministry of Defence, 2016. Forrás: issat.dcaf.ch [2019. 11. 08.]

Winn, Neil: Beyond Strategic Culture? Grand Strategy, the European Union and Security Cooperation. [online], Leeds, POLIS, 2015. Forrás: aei.pitt.edu [2019. 11. 02.]

Working Worldwide for the Security of the Netherlands. An Integrated International Security Strategy 2018-2022. [online], Ministry of Foreign Affairs, 2018. Forrás: government.nl [2019. 11. 01.] 